\section{Thirdhand smoke: when the danger is more than you can see or smell}

\author{
Thirdhand smoke: quando o perigo vai além do \\ que se vê ou sente
}

Thirdhand smoke: cuando el peligro va más allá de lo que se ve o se siente
Luciana Rizzieri Figueiró 1

Ana Luiza Ziulkoski 2

Denise Conceição Mesquita Dantas ${ }^{1}$

doi:10.1590/0102-311X00032216

\begin{abstract}
Recent discussion has focused on another form of exposure to tobaccothirdhand smoke (THS) - consisting of residual pollutants from cigarette smoke that remain in environments. The main concern with THS is based on the presence and persistence of many toxic compounds, some specific nitrosamines from tobacco that have carcinogenic activity. Little is known about THS, and few people are aware of its existence and potential health repercussions, thus highlighting the need to shed light on the subject and incorporate it into the public health debate, as was done with passive smoking several years ago. THS is a form of passive smoking, together with secondary or involuntary exposure to cigarette smoke.

Tobacco Smoke Pollution; Tobacco; Smoke
\end{abstract}

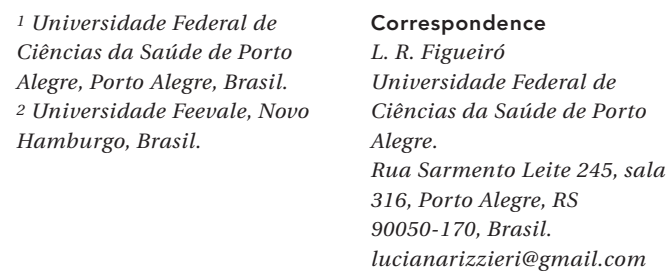

1 Universidade Federal de Ciências da Saúde de Porto Alegre, Porto Alegre, Brasil. 2 Universidade Feevale, Novo Hamburgo, Brasil.

\author{
Correspondence \\ L. R. Figueiró \\ Universidade Federal de \\ Ciências da Saúde de Porto \\ Alegre. \\ Rua Sarmento Leite 245, sala \\ 316, Porto Alegre, RS \\ 90050-170, Brasil.
}

lucianarizzieri@gmail.com 


\section{Introduction}

The World Health Organization (WHO) estimates that one-third of the world's adult population is exposed involuntarily to cigarette smoke 1 . In Brazil, $10.7 \%$ of non-smokers are exposed to smoke in their homes and $13.5 \%$ in their workplaces 2 . An estimated 600,000 non-smokers die in the world every year from exposure to passive smoking ${ }^{3}$.

A meta-analysis concluded that elderly nonsmokers living with smokers have $30 \%$ greater odds of suffering ischemic heart disease when compared to unexposed elders 4 . Individuals exposed simultaneously at home and in the workplace show double the odds of acute myocardial infarction 5. Due to environmental tobacco smoke (ETS), 3,000 deaths occur per year from lung cancer, and the odds of neoplasia are $35 \%$ greater in passive smokers ${ }^{6}$. Passive smoking is also associated with increased risk of type 2 diabetes mellitus, sinusitis, tuberculosis, and breast cancer $7,8,9,10$. There is sufficient evidence that passive smoking causes diseases and premature deaths in children and adults and that there are no safe levels of exposure to cigarette smoke ${ }^{11}$.

The harms to passive and involuntary smokers come from the substances released during the burning of tobacco. Cigarette smoke forms an aerosol of gases, vapors, and liquid particles that disperses homogeneously in the air, such that individuals are exposed to significant concentrations of these substances, regardless of distance from the source 12. Recent years have witnessed debate on the danger of contamination by tobacco's harmful substances, even after the cigarette has been put out. This exposure has been called thirdhand smoke (THS) 13 (in Brazil, the term's literal translation in Portuguese, fumo de terceira $m \tilde{a} o$, is still not widely used). THS consists of a mixture of volatile compounds and particulate matter that can be deposited or adsorbed on surfaces, including clothing, furniture, and upholstery 14 . The smoke that constitutes ETS changes both chemically and physically, especially over time $5,15,16$, so THS can also be called residual tobacco smoke or aged tobacco smoke 17. As soon as the smoke begins and until several hours later, THS and smoke coexist, with the predominance of THS as the smoke dissipates and is removed by ventilation 16,17 . The persistence of many toxic compounds, even if it is no longer possible to see or smell the smoke, is one of the main concerns over invisible exposure to THS 15,17.

Burton 18 described THS with three R's: smoke pollutants from tobacco products that remain in the environment and are re-emitted into the air or react with oxidants and other compounds from the environment to form secondary pollutants. Residues of the smoke re-suspended in the air cause contamination by inhalation, and residues deposited on surfaces can be absorbed by the oral or dermal route 19 . Passive smoking is no longer only involuntary exposure to cigarette smoke, but incorporates exposure to substances that remain or are formed in the environment after the smoke disperses 20.

In 2003, the Member States of the WHO, including Brazil, adopted the Framework Convention on Tobacco Control (FCTC), an international public health treaty that emphasizes the states' responsibility to create and enforce effective tobacco control programs 21. The FCTC sets standards to protect present and future generations from the devastating health, social, environmental, and economic consequences of tobacco consumption and exposure to tobacco smoke; the Convention thus aims at continuous and substantial reduction in the prevalence of consumption and exposure to smoke 22 .

Even before signing the FCTC, Brazil took a pioneering role by establishing its National Anti-Smoking Program, implementing important measures. Brazil's tobacco control policy has produced some of the greatest effects over the years. The proportion of Brazilian smokers dropped significantly, from $32 \%$ in 1989 to $15 \%$ in 2013 23. This reduction was due to numerous interventions, including a ban on cigarette advertising in the mass media and sponsorship of events by tobacco companies, tax hikes on tobacco products, health warnings on cigarette packs, awareness-raising campaigns, and greater availability of behavioral and pharmacological smoking cessation treatment in the public healthcare system, among others 24 . Federal Law $12,546 / 2011$, regulated in 2014 , with amendments to Law 9,294/1996, bans the use of tobacco products in all closed collective premises, both public and private 25,26 . One of the beneficial results of the "antismoking law" was a reduction in exposure of non-smokers to cigarette smoke in workplaces with closed environments, from $22.8 \%$ in 2008 to $13.5 \%$ in 2013 2,27. Indirectly, all the laws and measures to reduce active and passive smoking have also resulted in reduced exposure to THS.

With the enforcement of the protective measures recommended by the FCTC, there was an increase in " $100 \%$ tobacco-free environments", but such areas are located in the public domain or collective- use establishments. The convention fails to include places where people are most vulnerable: in their own homes or other places in which the legal instruments are unable to exercise strict control, as in private cars 28 . 
The first study on THS was published in 2009 and concentrated on the perception of such smoke's existence and the enforcement of rules to restrict smoking in smokers' homes in the United States 13. Almost at the same time, three more studies proposed to publish original findings on the topic, highlighting nicotine's persistence in the environment and the formation of carcinogenic substances $14,15,19$. In the following two years, more research was published in the form of editorials, letters to editors, or expert commentary $18,20,29,30,31,32$. The first publication in Portuguese was in 2015 as a letter to the editor 33 . More studies were developed, adding new evidence over the years 34,35 , but thus far scarcely more than 50 articles are retrieved in PubMed with the search term "thirdhand smoke". Little is known about THS, and few people know of its existence and repercussions on health. This emphasizes the need to focus attention on THS and include it in scientific and public health discussions, as was done with passive smoking several years ago, among other reasons because passive smoking includes THS.

\section{Retention of THS}

The first publication showing that nicotine persists in the indoor dust of smokers' homes dates to more than 20 years ago 36 . Ten years ago, Matt et al. 37 reported that even in environments in which smokers refrained from smoking, as in children's bedrooms, nicotine was detected in the house dust at levels five to seven times higher than in non-smokers' homes.

A single cigarette smoked on one day in a given environment can expose many people to the smoke's toxic compounds for days and even months ${ }^{38}$. Exposure to THS has been proven by several studies in recent years. In a study in California (USA) published in 2011, even two months after homes previously inhabited by smokers were vacated and a month after the new non-smoking residents moved in, nicotine was detected in the air, dust, and surfaces of the furniture in the bedroom and living room (Figure 1for comparison, the figure presents nicotine levels in houses formerly occupied by non-smokers and the limits used in the study to discriminate between smoking and non-smoking or between environments exposed versus unexposed to cigarette smoke). There was a considerable decrease in the amount of nicotine, but the reduction did not reach the levels found in homes formerly occupied by non-smokers. The study proved not only the persistence of THS, but also the exposure to new residents: nicotine on the fingertips of children who moved into homes formerly occupied by smokers was seven times higher and urinary cotinine (the principal metabolite of nicotine) was three times higher than when the former residents were non-smokers 14 .

Nicotine also accumulates in vehicles. In a truck's cab, the front lid to the glove compartment accumulated $0.6 \mu \mathrm{g} / \mathrm{cm}^{2}$ of nicotine and a strip of paper exposed for three days adsorbed $1.4 \mu \mathrm{g} / \mathrm{cm}^{2} 15$. In rental cars in California, even in those designated as non-smoking, nicotine was detected in the air, dust, and inside surfaces of the vehicles, clearly demonstrating the rental companies' failure to protect non-smokers from passive smoking. Table 1 shows the amount of nicotine found in the study, published in 201339. For comparison, information is also shown on nicotine concentration in non-smokers' private cars 40 . Various jurisdictions have laws against smoking in private vehicles with children onboard, including England, California, Australia, and Canada, among others 41. However, since nicotine and possibly other compounds remain inside the vehicle, this measure fails to completely protect occupants from THS exposure. Although Brazil has no law that prohibits smoking inside vehicles, article 252 of the Brazilian Traffic Code specifies that it is a violation to drive with only one hand, except in specific situations like changing gears, making hand signals, or operating the vehicle's instruments and accessories 42 . Smoking while driving can also be interpreted as inattention to essential safety measures. Thus, the tacit understanding is that drivers should not smoke while driving, but the situation is not seen routinely. Besides, Brazil has no rule that applies to passengers, so there is currently no way to prevent contamination of the inside of vehicles with cigarette smoke.

A study in hotels in California in 2014 (Table 2) showed that merely restricting cigarette smoke to some environments does not protect people. Non-smoking rooms in hotels without a complete restriction on smoking showed higher nicotine levels in the air, on the bedhead, and on the outside of the door when compared to hotels that were $100 \%$ cigarette-free. Guests in these rooms also showed higher levels of nicotine on their fingertips and cotinine in their urine 43 . As a collective use environment, smoking in hotels, even in partially closed environments, is banned in Brazil, so a study in such an environment serves as a warning that THS is ubiquitous, since THS is not confined to the space in which the cigarette was smoked 44 , but moves easily through the ventilation system, corridors, air ducts, windows, and doors. This underscores the inefficacy of designated smoking areas (banned 
Results reported by Matt et al. 14 in rental homes previously occupied by smokers and rental homes previously occupied by non-smokers and later occupied by non-smokers.

\begin{tabular}{|c|c|c|c|}
\hline \multicolumn{2}{|c|}{ Former residents } & Non-smokers & Cut-off * \\
\hline 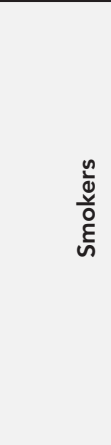 & $\begin{array}{c}\text { Nicotine in air } \\
\text { Living room: } 1.86 \mu \mathrm{g} / \mathrm{m}^{3} \\
\text { Bedroom: } 1.44 \mu \mathrm{g} / \mathrm{m}^{3} \\
\text { Nicotine on surfaces } \\
\text { Living room: } 98.7 \mu \mathrm{g} / \mathrm{m}^{2} \\
\text { Bedroom: } 50.1 \mu \mathrm{g} / \mathrm{m}^{2} \\
\text { Nicotine in dust } \\
\text { Living room: } 39.6 \mu \mathrm{g} / \mathrm{g} \\
\text { Bedroom: } 30.7 \mu \mathrm{g} / \mathrm{g} \\
\text { Nicotine on fingertips: } 660.21 \mathrm{ng} \\
\text { Urinary cotinine: } 5.42 \mathrm{ng} / \mathrm{mL}\end{array}$ & $\begin{array}{c}\text { Nicotine in air } \\
\text { Living room: } 0.2 \mu \mathrm{g} / \mathrm{m}^{3} \\
\text { Bedroom: } 0.12 \mu \mathrm{g} / \mathrm{m}^{3} \\
\text { Nicotine on surfaces } \\
\text { Living room: } 10.0 \mu \mathrm{g} / \mathrm{m}^{2} \\
\text { Bedroom: } 7.5 \mu \mathrm{g} / \mathrm{m}^{2} \\
\text { Nicotine in dust } \\
\text { Living room: } 10.9 \mu \mathrm{g} / \mathrm{g} \\
\text { Bedroom: } 11.0 \mu \mathrm{g} / \mathrm{g} \\
\text { Nicotine on fingertips: } 5.19 \mathrm{ng} \\
\text { Urinary cotinine: } 0.45 \mathrm{ng} / \mathrm{mL}\end{array}$ & $\begin{array}{c}\text { Nicotine in air } \\
0.1 \mu \mathrm{g} / \mathrm{m}^{3} \\
\text { Nicotine on surfaces } \\
5.0 \mu \mathrm{g} / \mathrm{m}^{2} \\
\text { Nicotine in dust } \\
5.0 \mu \mathrm{g} / \mathrm{g} \\
\text { Nicotine on fingertips }\end{array}$ \\
\hline 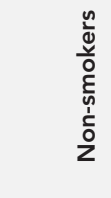 & $\begin{array}{c}\text { Nicotine in air: } 0.02 \mu \mathrm{g} / \mathrm{m}^{3} \\
\text { Nicotine on surfaces } 1.6 \mu \mathrm{g} / \mathrm{m}^{2} \\
\text { Nicotine in dust: } 2.9 \mu \mathrm{g} / \mathrm{g} \\
\text { Nicotine on fingertips: } 1.35 \mathrm{ng} \\
\text { Urinary cotinine: } 0.15 \mathrm{ng} / \mathrm{mL}\end{array}$ & $\begin{array}{c}\text { Nicotine in air: } 0.14 \mu \mathrm{g} / \mathrm{m}^{3} \\
\text { Nicotine on surfaces: } 1.5 \mu \mathrm{g} / \mathrm{m}^{2} \\
\text { Nicotine in dust: } 2.3 \mu \mathrm{g} / \mathrm{g} \\
\text { Nicotine on fingertips: } 0.75 \mathrm{ng} \\
\text { Urinary cotinine: } 0.13 \mathrm{ng} / \mathrm{mL}\end{array}$ & $\begin{array}{c}\text { Urinary cotinine } \\
0.30 \mathrm{ng} / \mathrm{mL}\end{array}$ \\
\hline
\end{tabular}

* Used to discriminate between smoking and non-smoking or between environments exposed versus unexposed to cigarette smoke.

Note: indoor measurements in homes first occupied by non-smokers were taken in the living room.

\begin{tabular}{|c|c|c|c|}
\hline & \multicolumn{2}{|c|}{ Rental cars 38} & \multirow{2}{*}{$\begin{array}{l}\text { Private cars } 39 \\
\text { Non-moking }\end{array}$} \\
\hline & Non-smoking & Smoking & \\
\hline Nicotine in air $\left(\mu \mathrm{g} / \mathrm{m}^{3}\right)$ & $0.024(0.008-0.063)$ & $0.050(0.018-0.086)$ & $0.010(0.000-0.010)$ \\
\hline Nicotine on surfaces $\left(\mu \mathrm{g} / \mathrm{m}^{2}\right)$ & $0.200(0.000-1.200)$ & $0.900(0.300-2.900)$ & $0.000(0.000-0.070)$ \\
\hline Nicotine in dust $(\mu \mathrm{g} / \mathrm{g})$ & $8.100(4.900-28.600)$ & $33.200(16.800-52.100)$ & $3.100(1.500-6.000)$ \\
\hline
\end{tabular}

Note: data presented as medians (25th percentile - 75th percentile). For smoking cars, the older the car and the greater the mileage, the higher the nicotine concentration in the dust and on surfaces.

in Brazil) in protecting non-smokers. Even the homes of smokers who do not allow indoor smoking show considerable levels of nicotine on surfaces 45 . Rooms in a neonatal intensive care unit in which the infant's caregiver was a smoker showed significant nicotine levels on surfaces of the furnishings reaching $34.2 \mu \mathrm{g} / \mathrm{cm}^{2}$. These infants also presented detectable levels of nicotine metabolites in their urine 46 . Persons themselves can be a vehicle for such pollutants, adsorbed on their clothing, skin, and hair and later deposited on the surfaces of other environments and causing contamination of other individuals who have not even had any contact with the cigarette smoke. This characteristic of THS has been called the "grasshopper effect", alluding to the components' capacity to "hop" from one environment to another 47,48 . 


\begin{tabular}{lccc}
\hline & $100 \%$ smoke-free hotels & $\begin{array}{c}\text { Hotels without complete restriction on smoking } \\
\text { Smoking rooms } \\
\text { Non-smoking rooms }\end{array}$ & $0.703(0.202-1.609)$ \\
\hline Nicotine in air $\left(\mu \mathrm{g} / \mathrm{m}^{3}\right)$ & $0.023(0.008-0.050)$ & $0.036(0.013-0.118)$ & $77.000(7.300-353.200)$ \\
Nicotine on surface $\left(\mu \mathrm{g} / \mathrm{m}^{2}\right)$ & $1.200(0.000-3.400)$ & $3.30(0.000-10.300)$ & $93.70(44.200-251.100)$ \\
Nicotine on fingertips $(\mathrm{ng})$ & $2.500(0.000-10.900)$ & $13.6(0.000-41.300)$ & $0.640(0.230-0.970)$ \\
Urinary cotinine $(\mathrm{ng} / \mathrm{mL})$ & $0.050(0.000-0.250)$ & $0.1(0.000-0.170)$ & 0.900 \\
\hline
\end{tabular}

Note: data presented as medians (25th percentile -75 th percentile).

Source: Matt et al. 42.

Non-smokers' homes showed quantifiable levels of nicotine in the dust (median $=2.3 \mu \mathrm{g} / \mathrm{g}$ ), but ten times lower than in smokers' homes. Smokers' homes, even when no one smoked indoors, showed a correlation between nicotine concentration and the number of cigarettes smoked by the residents 49 . This emphasizes that cigarette smoke's components are released into the environment by routes other than the mainstream (smoke exhaled by smokers during puffs) and sidestream (smoke emanating from the smoldering cigarette tip). Any tobacco byproduct that generates smoke can contribute to the formation of THS. Bedrooms of children in homes where hookahs were the only form of tobacco use showed higher nicotine levels in the air and on surfaces when compared to non-smokers' homes, even when the hookah was only smoked a few times per week or month 50 .

Nicotine's persistence has also been analyzed experimentally. Cotton and polyester fabrics were exposed continuously to cigarette smoke for a year and eight months, respectively, and analyzed after 11, 16, and 19 months. Considerable amounts of nicotine were only detected in the cotton fabric $(105.8 \mu \mathrm{g} / \mathrm{g}, 112.9 \mu \mathrm{g} / \mathrm{g}$, and $69.9 \mu \mathrm{g} / \mathrm{g}$ of fabric, respectively) 51 . Even electronic cigarettes using nicotine refills increased the amount of the substance deposited on surfaces. On floor tiles, the place that accumulated the most nicotine, the amount increased from practically zero before the use of electronic cigarettes to $205 \mu \mathrm{g} / \mathrm{m}^{2}$ after 100 puffs 52 . Studies are needed on electronic cigarettes, since they have been viewed by the general population and sold as less harmful and as a strategy to achieve cessation, but there is no evidence that these devices are effective to quit smoking, and there is still limited information on their safety 53,54. Besides, e-cigarettes have been used in the attempt to fool $100 \%$ cigarette smoke-free environments, but the level of nicotine released into the environment is higher than demonstrated in studies on "tra- ditional cigarettes", thus emphasizing that such devices require regulation as to areas where their use is allowed, since their residues can persist in the environment and act as a source of exposure to non-smokers.

\section{THS composition}

Other compounds besides nicotine have been identified in THS. In rental cars and hotel rooms where smoking was permitted, levels of 3ethynylpyridine (3-EP) in the air were higher than in cars and rooms in which smoking was prohibited 39,43. Meanwhile, levels of the substance deposited on furniture surfaces did not differ between smoking and non-smoking rooms in the hotels 43 . The only semi-volatile amine found in the gaseous phase two hours after burning the cigarette was 3-EP, but it later disappeared (at 18 hours), probably due to the high adsorption to surfaces 55 .

Nicotine desorbed from surfaces and reemitted into the ambient air may form secondary pollutants by reacting with atmospheric oxygen and nitrogen species ${ }^{17}$. Nicotine undergoes a nitrosation from nitrous acid (HONO) to form the tobacco-specific nitrosamines 4-(methylnitrosamine)-1-(3-pyridil)-1-butanone (NNK), N'-nitrosonornicotine (NNN), N-nitrosopyrrolidine (NPYR), and 4-(methyl-nitrosamino)-4-(3pyridyl)-butanal (NNA) 15. HONO is present in high concentrations in indoor air, since it results from direct emissions from combustion equipment without ventilation, cigarette smoke, and conversion of $\mathrm{NO}_{2}$ and NO. The ready availability of agents that promote the formation of these nitrosamines is important, since NNK and NNN have carcinogenic activity ${ }^{56}$. NNA is absent from recently emitted smoke, due to its high instability at high temperatures; its mutagenic activity is similar to that of NNN 57. 
Many nitrosamines are natural components of cigarette smoke 56 , and when they are present in THS it is difficult to determine their precise origin, whether already existing in the cigarette smoke or formed through reactions with nicotine. Approximately $80 \%$ of nitrosamines are deposited on the surfaces of environments and are not removed by normal ventilation 58 . NNK has been found on the surfaces of nearly all homes and cars of smokers, but is found only occasionally in nonsmokers' homes ${ }^{59}$. Ramírez et al. 49 found that the concentration of five tobacco-specific nitrosamines (including NNN, NNK, and its metabolite 4-(methyl-nitrosamino)-1-(3-pyridyl)-1-butanol - NNAL) and eight other volatile nitrosamines was some eight times higher in the indoor dust of smokers' as compared to non-smokers' homes 49 . A subsequent study detected other carcinogenic aromatic amines for the first time, with the greatest abundance of 2-aminonaphthalene and 4 -aminobiphenyl in smokers' homes 60 . NNAL was detected in the urine of mice exposed only to THS 61 . A study on the effect of time on the concentration of nitrosamines deposited on cotton fabric found that NNK levels increased up to 16 months and decreased three months later. The increase also occurred in the concentration of NNN, and NNA dropped from 16 to 19 months. The increase was explained by the de novo formation of nitrosamines from nicotine deposited on the material before reaching a limit and beginning to decay due to chemical transformations 51 . De novo formation of these nitrosamines was also proven in a longitudinal experiment by the increase in concentration during months in which there was no exposure to cigarette smoke 62 .

Other byproducts are formed by nicotine's reaction with the ozone $\left(\mathrm{O}_{3}\right)$ from air contamination with outdoor air pollutants and the use of air purifiers 63,64 . Nicotine's reaction with ozone forms cotinine, formaldehyde, n-methyl-formamide, and nicotinaldehyde 65 . In a controlled setting that used a chamber to simulate a real environment, the presence of $\mathrm{O}_{3}$ did not lead to the reemission of nicotine to the gaseous phase, but to products of nicotine's oxidation ( $\mathrm{N}$-methylformamide and miosmine). The chamber walls yielded nicotine, nicotine-1-oxide, and two organophosphates that are absent from cigarette smoke but are commonly used in flame retardant formulations 63 .

Sleiman et al. 55 suggested that chlorinated compounds and chloride ions could react and form chloromethane and dichloromethane, two substances that are not usually present in ETS. Pesticide residues in tobacco and in the bleaching agents used in cigarette paper are the probable sources of these chlorinated compounds.
Cigarette smoke is a significant source of exposure to polycyclic aromatic hydrocarbons (PAHs), a group of substances with carcinogenic potential 66. PAHs result from the incomplete combustion or pyrolysis of organic materials 67 ; there are few studies on their persistence in THS. The amount of PAHs on smokers' hands was nearly three times that on non-smokers' hands 68 . PAH levels in house dust in smokers' homes were double those in non-smokers' homes. There was also a positive correlation between PAH levels in the living room (where the smoker smoked) and the bedroom of a non-smoking resident, showing that these substances can be transported to environments in which smoking is not permitted 47 . Approximately $60 \%$ of the PAHs present in cigarette smoke are deposited on surfaces in the environments 58 .

Different types of fabric impregnated with cigarette smoke desorbed many volatile organic compounds while staying 30 minutes in a smokefree environment. The concentration released was lower than levels typically found in secondary smoke, and compounds with greater volatility desorbed more rapidly from the fabrics (10 minutes). Like particulate matter, the substances benzene, 2,5-dimethyl-furane (2,5-DMF), and toluene are found in the air exhaled by smokers up to ten minutes after they stop smoking 69,70. Many other compounds not usually reported in ETS have been detected in laboratory studies using a machine to release cigarette smoke in a chamber, such as metacrolein, methyl-vinyl-ketone, 2-methylfuran, 1,3-pentadiene, 1-butene, and propanonitrile. The concentration of volatile compounds taper off over time, and nicotine was only detected in the air up to 20 minutes after the flame was extinguished, and was inexistent after two hours. Meanwhile, the levels of some compounds increased, indicating reemission or reaction and de novo formation of the compounds. Eight hours after the last cigarette was smoked in the house, some pollutants were found exclusively or predominantly indoors. Therefore, acetonitrile, 2,5-DMF, 2-methylfuran, p-xylene, acrolein, benzaldehyde, metacrolein, heptane, undecane, 1-nonene, and isoprene may be useful markers of THS 55 .

\section{Effects of THS on health}

The risk of individuals' exposure to THS components is still not totally clear, since there are few studies on its effects. However, the presence and persistence of toxic compounds with harmful health effects mean that the danger THS cannot be ignored. Half of the nicotine deposited on 
clothing and dissolved by sweat can penetrate the body through the skin and be absorbed 71 . There is no clear linear relationship between the exposure dose to THS and harmful effects 72,73 .

Children are more susceptible to THS, since they spend more time indoors and breathe closer to the floor, where dust accumulates, in addition to moving objects from hand to mouth after touching contaminated surfaces 13 . Children are also more vulnerable because they have a higher respiratory rate in relation to their body size, more immature respiratory and immune systems, and lower metabolic capacity ${ }^{44}$. Previously cited studies proved the exposure of children and the environments in which they live to THS even if they are not exposed to the smoke during its emission 14,45,46,50. However, there are still few studies on the effects of THS on children's health. According to a study in South Korea with 31,584 children 6 to 11 years of age, dry cough, nighttime cough, and coughing fits were associated with exposure to THS 74 . The irritating products generated by oxidation of cigarette smoke's components may be the principal factors responsible for these respiratory symptoms 63 .

Ramírez et al. 49 estimated the risk of cancer from exposure to carcinogens in THS. The greatest risk was for children one to six years of age exposed to nicotine and others substances deposited in the dust in smokers' homes (9.6 additional cancer cases per 100,000 children exposed). In non-smokers' homes, the risk was one-third as high. The maximum risk of exposure to all nitrosamines from THS in smokers' homes was one extra case of cancer per thousand persons exposed.

In a bacterial model to mimic the action of $\mathrm{N}_{2}$ and $\mathrm{O}_{3}$ on a surface impregnated with nicotine, no mutagenic effect was observed in different strains of Salmonella typhimurium (Ames test) 19. Meanwhile the genotoxic effect was observed in human hepatocellular carcinoma cells (HepG-2) exposed to THS, resulting in increased DNA strand breaks using the comet assay 72 . Murine neural stem cells (mNSC) and human dermal fibroblasts (hDF) were exposed to a culture medium prepared with fabric material present inside automobiles from which THS was collected and evaluated with the comet assay. Cells treated with this material showed a higher percentage with migration of chromosomal DNA and longer tails 62. Chronic exposure to THS resulted in oxidative DNA damage in genes involved in nucleotide metabolism and repair mechanism in human bronchial epithelial cells (BEAS-2B) ${ }^{72}$. In addition, together with NNK, NNA can induce base mutation in DNA and result in uncontrolled cell growth and thus tumor formation 35 .
THS cytotoxicity was verified by altered mitochondrial function in mNSC, but the potential for damage decreased as the sample aged $62,75,76$. There was even a decrease in the total number of cells, caused by inhibition of cell proliferation. THS also led to decreased growth, lower cell motility, and greater occurrence of cellular alterations, such as vacuoles, fragmentation, and cytoplasm loss 62,75. In addition, decreased cell viability, as assessed by the amount of protein, was found in fibroblasts of mice (L929) exposed to THS 71 .

Even at concentrations incapable of causing cytotoxic effects, two murine male reproductive cell lines (GC-2 and TM-4), when exposed to THS, presented altered metabolite levels and gene expression of enzymes related to metabolism and oxidative stress 76 . The study warned of THS action on systems that are not the prime target of cigarette smoke, but which can have their function compromised by continuous exposure. Exposure to THS also led to shorter dendritic length and altered heartbeat in zebrafish embryos 71 .

Martins-Green et al. 61 and Karim et al. 73 investigated the effects attributed only to THS. Mice exposed to THS presented altered levels of triglycerides, fasting glucose, lipids, and fatty liver (steatosis), collagen production, alveolar thickness and structure including cellular infiltration, and pro-inflammatory cytokines 61 , as well as increased platelet aggregation and secretion, resulting in shorter bleeding time and increased risk of thrombosis 73 . Alterations in liver metabolism show potential risk for diabetes, myocardial infarction, and other cardiovascular diseases, with thrombosis as the principal mechanism in mortality from cardiovascular disease associated with smoking 18 . Meanwhile, elevated interstitial collagen level, thickened walls, and presence of macrophages in the alveoli and elevated levels of pro-inflammatory cytokines confer elevated risk of developing pulmonary fibrosis after prolonged exposure to THS 61 . In addition, using the nitrosamines NNK and NNA as surrogates for THS in rat lung explants led to interruption of homeostasis signaling, altering the levels of proteins that affect lung development, such as peroxisome proliferator-activated receptor gamma (PPAR- $\gamma$ ), fibronectin, and calponin 77 .

As additional evidence of the impact of THS on health, fine particles contribute to more than $90 \%$ of the total damage caused by involuntary smoking and THS. A non-smoker living 50 years with a smoker can lose 0.3 to 7 years of life from inhaling toxic compounds from THS. Even if both individuals spend most of their time away from home, non-smokers can lose 0.3 to 4.1 years of life due to this exposure. Depending on the time 
transpired until the transition to THS, 5\% to $60 \%$ of the total damage caused by exposure to cigarette smoke pollutants in the environment can be attributed exclusively to THS 55 .

Behavioral disorders are more common in children exposed involuntarily to cigarette smoke 78 , while the impact of THS on behavior has received little research. Animals exposed to THS displayed hyperactivity-type behavior, running longer and faster in the open field test than unexposed animals 61 . In addition, children exposed to THS in the home which reacted positively to cigarette smell from objects or persons (in other words, children that felt pleasure or euphoria or simply liked the smell) were more prone to smoke a cigarette if a friend offered one. Thus, reactions to THS and the tendency to smoke can be socially influenced and act as a risk factor for smoking initiation 79 .

\section{Making the danger visible}

Although viewed with skepticism by some 17,29, a national telephone survey in the United States published in 2009 found that $61 \%$ of nearly 1,500 adults acknowledged THS as harmful to children, while $22 \%$ had no opinion 13 . Another study in private pediatric offices in various counties in the United States from 2009 to 2011 found that $91 \%$ of parents who smoked believed that THS could harm their children 80 . In low-income communities in Georgia (USA), more individuals were worried about THS harming their children than involuntary smoking causing heart diseases 38 . Hispanics living in residential buildings in California were unfamiliar with the term THS, while admitting that although they banned smoking in their own homes, they were unable to effectively avoid exposure to cigarette smoke coming from their neighbors 81 . The problem of contamination of multiunit dwellings like apartment buildings, condos, and row houses is a challenge for any tobacco control policy.

Smokers who believed that THS could be harmful to children's health were significantly more prone to adopt measures to restrict smoking in their homes and vehicles 13,80. Discussion with smokers on the effects of THS can provide a further reason for encouraging smoking cessation or adopting procedures to prevent exposure of non-smokers to cigarette smoke and THS. Concern for one's own health is generally reported as the main reason for smokers to try quitting 82,83 , but a review that included studies spanning more than 30 years found that smoking's effect on family members was a frequent reason for attempting to quit 84 .
Concern over the effects of THS on children's health is particularly important. Children have age-specific physiological characteristics, as discussed above, and limited autonomy in relation to their immediate surroundings (when family members smoke in their presence they have no way to avoid exposure to the smoke). They are thus the most defenseless population vis-à-vis the effects of cigarette smoke and thirdhand smoke ${ }^{85}$. One of the Sustainable Development Goals (SDGs) of the United Nations Development Program (UNDP) is to ensure children's quality of health, which includes decreasing infant mortality 86 . Reducing involuntary exposure to cigarette smoke helps meet this goal, since strong evidence shows that exposure to smoke increases infant mortality 87 . Strengthening implementation of the FCTC is also one of the SDGs approved by the UNDP, and the two goals' convergence emphasizes the importance of on-going research on THS in children to generate evidence allowing Brazil and other countries to further strengthen the struggle against the tobacco epidemic and thus achieve healthier living.

Since Brazil has no law against smoking in people's own homes, raising smokers' awareness of the risks of THS to their families may be an effective strategy for smokers to refrain from smoking in areas shared by their non-smoking family members. In fact, among light smokers there was an important decline in passive smoking from 2008 to 2013, suggesting that smokers who continue to smoke are considering social disapproval of smoking as a reason for quitting 23. It is unlikely or even impossible (for ethical reasons involving individual freedom) that specific legislation will be created to ban the use of tobacco products in private residences; therefore, education and awareness-raising on the effects of THS may be useful strategies. The impact of THS on health, and especially that of children, could be the theme for campaigns to reach individuals concerned about their family's welfare.

\section{Final remarks}

Thirdhand smoke is not harmless. The few studies on its effects serve as a warning that contaminated fabric and surfaces have the potential to cause adverse health effects, even when there is no immediate contact with the smoke. The risks of THS are still unknown to the population at large, so mobilization of public opinion to better understand its harmful effects should be part of tobacco control programs.

Even ventilation and air cleaning systems are ineffective in preventing exposure to the com- 
ponents of cigarette smoke, so the only way to eliminate non-smokers' exposure to passive smoking is to totally prevent active smoking in closed spaces. Despite progress in decreasing the proportion of smokers and behavior changes among the remaining smokers in Brazil, which has resulted in a reduction in passive smoking, it is still a challenge for tobacco control policies to protect all non-smokers from involuntary exposure to smoke and THS. Fulltime $100 \%$ tobacco-free environments are thus needed, adopting restrictions on smoking to protect non-smokers in private residences and environments. Meanwhile, many of the components of THS are carried from one place to another by smokers them- selves, which may make it impossible to guarantee complete absence of exposure to non-smokers, so awareness-raising on the harms caused by THS could be used clinically to encourage smoking cessation.

In short, while there is scientific evidence on the harms of involuntary smoking for individuals' health, and there is no way to deny the existence of THS, little is known about this pollutant's mechanisms of action, as a whole or for its components. Not all of the components have been identified. The potential effects of THS on individual and public health highlight the need for more research to prove or disprove such risks and encourage an evidence-based debate.

\section{Contributors}

L. R. Figueiró, A. L. Ziulkoski and D. C. M. Dantas contributed substantially to the paper's conception and planning and critical revision of the content, and revised and approved the manuscript's final version.

\section{References}

1. World Health Organization. Selected pollutants: WHO guideline for indoor air quality. http://www. who.int/indoorair/publications/9789289002134/ en/ (accessed on 24/Sep/2015).

2. Instituto Brasileiro de Geografia e Estatística. Pesquisa Nacional de Saúde 2013. Percepção do estado de saúde, estilos de vida e doenças crônicas. Brasil, Grandes Regiões e Unidades da Federação. Rio de Janeiro: Instituto Brasileiro de Geografia e Estatística; 2014.

3. World Health Organization. WHO global report: mortality attributable to tobacco. http:// apps.who.int/iris/bitstream/10665/44815/1/978 9241564434_eng.pdf (accessed on 05/May/2016).

4. Law MR, Morris JK, Wald NJ. Environmental tobacco smoke exposure and ischaemic heart disease: an evaluation of the evidence. BMJ 1997; 315:973-80.

5. Panagiotakos DB, Chrysohoou C, Pitsavos C, Papaioannou I, Skoumas J, Stefanadis C, et al. The association between secondhand smoke and the risk of developing acute coronary syndromes, among non-smokers, under the presence of several cardiovascular risk factors: the CARDIO2000 casecontrol study. BMC Public Health 2002; 2:9.

6. U.S. Environmental Protection Agency. Respiratory health effects of passive smoking: lung cancer and other disorders. Washington DC: U.S. Environmental Protection Agency, Office of Research and Development, Office of Health and Environmental Assessment; 1992. 
7. Dogar OF, Pillai N, Safdar N, Shah SK, Zahid R, Siddiqi K. Second-hand smoke and the risk of tuberculosis: a systematic review and a meta-analysis. Epidemiol Infect 2015; 143:3158-72.

8. Eze IC, Schaffner E, Zemp E, von Eckardstein A, Turk A, Bettschart R, et al. Environmental tobacco smoke exposure and diabetes in adult neversmokers. Environ Health 2014; 13:74.

9. Hur K, Liang J, Lin SY. The role of secondhand smoke in sinusitis: a systematic review. Int Forum Allergy Rhinol 2014; 4:22-8.

10. Johnson KC, Glantz SA. Evidence secondhand smoke causes breast cancer in 2005 stronger than for lung cancer in 1986. Prev Med 2008; 46:492-6.

11. U.S. Department of Health and Human Services. The health consequences of involuntary exposure to tobacco smoke: a report of the surgeon general. Washington DC: U.S. Department of Health and Human Services, Centers for Disease Control and Prevention, Coordinating Center for Health Promotion, National Center for Chronic Disease Prevention and Health Promotion, Office on Smoking and Health; 2006.

12. Araújo AJ, Menezes AMB, Dórea AJPS, Torres BS, Viegas CAA, Silva CAR, et al. Diretrizes para cessação do tabagismo. J Bras Pneumol 2004; 30 Suppl 2:S1-76.

13. Winickoff JP, Friebely J, Tanski SE, Sherrod C, Matt GE, Hovell MF, et al. Beliefs about the health effects of "thirdhand" smoke and home smoking bans. Pediatrics 2009; 123:e74-9.

14. Matt GE, Quintana PJ, Zakarian JM, Fortmann AL, Chatfield DA, Hoh E, et al. When smokers move out and non-smokers move in: residential thirdhand smoke pollution and exposure. Tob Control 2011; 20:e1.

15. Sleiman M, Gundel LA, Pankow JF, Jacob 3rd P, Singer BC, Destaillats H. Formation of carcinogens indoors by surface-mediated reactions of nicotine with nitrous acid, leading to potential thirdhand smoke hazards. Proc Natl Acad Sci U S A 2010; 107:6576-81.

16. Schick SF, Glantz SA. Sidestream cigarette smoke toxicity increases with aging and exposure duration. Tob Control 2006; 15:424-9.

17. Matt GE, Quintana PJ, Destaillats H, Gundel LA, Sleiman M, Singer BC, et al. Thirdhand tobacco smoke: emerging evidence and arguments for a multidisciplinary research agenda. Environ Health Perspect 2011; 119:1218-26.

18. Burton A. Does the smoke ever really clear? Thirdhand smoke exposure raises new concerns. Environ Health Perspect 2011; 119:A70-4.

19. Petrick LM, Svidovsky A, Dubowsky Y. Thirdhand smoke: heterogeneous oxidation of nicotine and secondary aerosol formation in the indoor environment. Environ Sci Technol 2011; 45:328-33.

20. Protano C, Vitali M. The new danger of thirdhand smoke: why passive smoking does not stop at secondhand smoke. Environ Health Perspect 2011; 119:A422.

21. World Health Organization. Framework convention on tobacco control. http://www.who.int/fctc/ text_download/en/index.html (accessed on 25/ Jun/2008).
22. Ministério da Saúde; Instituto Nacional de Câncer. Programa nacional de controle do tabagismo e outros fatores de risco de câncer. Rio de Janeiro: Instituto Nacional de Câncer; 2003.

23. Szklo AS, de Souza MC, Szklo M, de Almeida LM. Smokers in Brazil: who are they? Tob Control 2016; 25:564-70.

24. Cavalcante TM. O controle do tabagismo no Brasil: avanços e desafios. Rev Psiquiatr Clín 2005; 32:283-300.

25. Brasil. Lei no 12.546, de 14 de dezembro de 2011. Diário Oficial da União 2011; 15 dez.

26. Brasil. Lei Federal no 9294, de 15 de julho de 1996. Diário Oficial da União 2011; 16 jul.

27. Instituto Nacional de Câncer. Global adult tobacco survey, Brazil 2008. Rio de Janeiro: Instituto Nacional de Câncer; 2010.

28. Samet JM, Chanson D, Wipfli H. The challenges of limiting exposure to THS in vulnerable populations. Curr Environ Health Rep 2015; 2:215-25.

29. Tuma RS. Thirdhand smoke: studies multiply, catchy name raises awareness. J Natl Cancer Inst 2010; 102:1004-5.

30. Dreyfuss JH. Thirdhand smoke identified as potent, enduring carcinogen. CA Cancer J Clin 2010; 60:203-4.

31. Schick SF. Thirdhand smoke: here to stay. Tob Control 2011; 20:1-3.

32. Tillett $\mathrm{T}$. Thirdhand smoke in review: research needs and recommendations. Environ Health Perspect 2011; 119:a399.

33. Oliveira MJ, Franco I, Gonçalves A, Pascoal I. O tabagismo em terceira mão: um conceito a (re)lembrar! Acta Med Port 2015; 28:676-7.

34. Quintana PJ, Matt GE, Chatfield D, Zakarian JM, Fortmann AL, Hoh E. Wipe sampling for nicotine as a marker of thirdhand tobacco smoke contamination on surfaces in homes, cars, and hotels. Nicotine Tob Res 2013; 15:1555-63.

35. Acuff L, Fristoe K, Hamblen J, Smith M, Chen J. Third-hand smoke: old smoke, new concerns. J Community Health 2016; 41:680-7.

36. Hein HO, Suadicani P, Skov P, Gyntelberg F. Indoor dust exposure: an unnoticed aspect of involuntary smoking. Arch Environ Health 1991; 46:98-101.

37. Matt GE, Quintana PJ, Hovell MF, Bernert JT, Song S, Novianti N, et al. Households contaminated by environmental tobacco smoke: sources of infant exposures. Tob Control 2004; 13:29-37.

38. Escoffery C, Bundy L, Carvalho M, Yembra D, Haardörfer R, Berg C, et al. Third-hand smoke as a potential intervention message for promoting smoke-free homes in low-income communities. Health Educ Res 2013; 28:923-30.

39. Matt GE, Fortmann AL, Quintana PJ, Zakarian JM, Romero RA, Chatfield DA, et al. Towards smokefree rental cars: an evaluation of voluntary smoking restrictions in California. Tob Control 2013; 22:201-7.

40. Matt GE, Quintana PJ, Hovell MF, Chatfield D, Ma DS, Romero R, et al. Residual tobacco smoke pollution in used cars for sale: air, dust, and surfaces. Nicotine Tob Res 2008; 10:1467-75. 
41. Thomson G, Wilson N. Public attitudes to laws for smoke-free private vehicles: a brief review. Tob Control 2009; 18:256-61.

42. Departamento Nacional de Trânsito. Código de Trânsito Brasileiro: instituído pela Lei no 9.503, de 23-9-97. $3^{a}$ Ed. Brasília: Departamento Nacional de Trânsito; 2008.

43. Matt GE, Quintana PJ, Fortmann AL, Zakarian JM, Galaviz VE, Chatfield DA, et al. Thirdhand smoke and exposure in California hotels: non-smoking rooms fail to protect non-smoking hotel guests from tobacco smoke exposure. Tob Control 2014; 23:264-72.

44. Ferrante G, Simoni M, Cibella F, Ferrara F, Liotta G, Malizia V, et al. Third-hand smoke exposure and health hazards in children. Monaldi Arch Chest Dis 2013; 79:38-43.

45. Northrup TF, Matt GE, Hovell MF, Khan AM, Stotts AL. Thirdhand smoke in the homes of medically fragile children: assessing the impact of indoor smoking levels and smoking bans. Nicotine Tob Res 2016; 18:1290-8.

46. Northrup TF, Khan AM, Jacob 3rd P, Benowitz NL, Hoh E, Hovell MF, et al. Thirdhand smoke contamination in hospital settings: assessing exposure risk for vulnerable paediatric patients. Tob Control 2015; Epub ahead of print.

47. Hoh E, Hunt RN, Quintana PJ, Zakarian JM, Chatfield DA, Wittry BC, et al. Environmental tobacco smoke as a source of polycyclic aromatic hydrocarbons in settled household dust. Environ Sci Technol 2012; 46:4174-83.

48. Lioy PJ. Employing dynamical and chemical processes for contaminant mixtures outdoors to the indoor environment: the implications for total human exposure analysis and prevention. J Expo Sci Environ Epidemiol 2006; 16:207-24.

49. Ramírez N, Ozel MZ, Lewis AC, Marcé RM, Borrull F, Hamilton JF. Exposure to nitrosamines in thirdhand tobacco smoke increases cancer risk in nonsmokers. Environ Int 2014; 71:139-47.

50. Kassem NO, Daffa RM, Liles S, Jackson SR, Kassem NO, Younis MA, et al. Children's exposure to secondhand and thirdhand smoke carcinogens and toxicants in homes of hookah smokers. Nicotine Tob Res 2014; 16:961-75.

51. Bahl V, Jacob 3rd P, Havel C, Schick SF, Talbot P. Thirdhand cigarette smoke: factors affecting exposure and remediation. PLoS One 2014; 9:e108258.

52. Goniewicz ML, Lee L. Electronic cigarettes are a source of thirdhand exposure to nicotine. Nicotine Tob Res 2015; 17:256-8.

53. Franck C, Filion KB, Kimmelman J, Grad R, Eisenberg MJ. Ethical considerations of e-cigarette use for tobacco harm reduction. Respir Res 201; 617:53.

54. Kuschner WG, Reddy S, Mehrotra N, Paintal HS. Electronic cigarettes and thirdhand tobacco smoke: two emerging health care challenges for the primary care provider. Int J Gen Med 2011; 4:115-20.

55. Sleiman M, Logue JM, Luo W, Pankow JF, Gundel LA, Destaillats H. Inhalable constituents of thirdhand tobacco smoke: chemical characterization and health impact considerations. Environ Sci Technol 2014; 48:13093-101.
56. Hecht SS. Progress and challenges in selected areas of tobacco carcinogenesis. Chem Res Toxicol 2008; 21:160-71.

57. International Agency for Research on Cancer. Tobacco habits other than smoking; betel-quid and areca-nut chewing; and some related nitrosamines. IARC Monogr Eval Carcinog Risk Chem Hum 1985; 37:1-268.

58. Schick SF, Farraro KF, Perrino C, Sleiman M, van de Vossenberg G, Trinh MP, et al. Thirdhand cigarette smoke in an experimental chamber: evidence of surface deposition of nicotine, nitrosamines and polycyclic aromatic hydrocarbons and de novo formation of NNK. Tob Control 2014; 23:152-9.

59. Thomas JL, Hecht SS, Luo X, Ming X, Ahluwalia JS, Carmella SG. Thirdhand tobacco smoke: a tobacco-specific lung carcinogen on surfaces in smokers' homes. Nicotine Tob Res 2014; 16:26-32.

60. Ramírez N, Vallecillos L, Lewis AC, Borrull F, Marcé RM, Hamilton JF. Comparative study of comprehensive gas chromatography-nitrogen chemiluminescence detection and gas chromatography-ion trap-tandem mass spectrometry for determining nicotine and carcinogen organic nitrogen compounds in thirdhand tobacco smoke. J Chromatogr A 2015; 1426:191-200.

61. Martins-Green M, Adhami N, Frankos M, Val$\operatorname{dez}$ M, Goodwin B, Lyubovitsky J, et al. Cigarette smoke toxins deposited on surfaces: implications for human health. PLoS One 2014; 9:e86391.

62. Bahl V, Shim HJ, Jacob 3rd P, Dias K, Schick SF, Talbot P. Thirdhand smoke: chemical dynamics, cytotoxicity, and genotoxicity in outdoor and indoor environments. Toxicol In Vitro 2016; 32:220-31.

63. Petrick L, Sleiman M, Dubowski Y, Gundel LA, Destaillats $\mathrm{H}$. Tobacco smoke aging in the presence of ozone: a room-sized chamber study. Atmos Environ 2011; 45:4959-65.

64. Sleiman M, Destaillats H, Smith JD, Liu C, Ahmed $\mathrm{M}$, Wilson KR, et al. Secondary organic aerosol formation from ozone-initiated reactions with nicotine and secondhand tobacco smoke. Atmos Environ 2010; 44:4191-8.

65. Destaillats H, Singer BC, Lee SK, Gundel LA. Effect of ozone on nicotine desorption from model surfaces: evidence for heterogeneous chemistry. Environ Sci Technol 2006; 40:1799-805.

66. IARC Working Group on the Evaluation of Carcinogenic Risks to Humans. Some non-heterocyclic polycyclic aromatic hydrocarbons and some related exposures. IARC Monogr Eval Carcinog Risks Hum 2010; 92:1-853.

67. Moir D, Rickert WS, Levasseur G, Larose Y, Maertens R, White P, et al. A comparison of mainstream and sidestream marijuana and tobacco cigarette smoke produced under two machine smoking conditions. Chem Res Toxicol 2008; 21:494-502.

68. Fleming T, Anderson C, Amin S, Ashley J. Thirdhand tobacco smoke: significant vector for PAH exposure or non-issue? Integr Environ Assess Manag 2012; 8:763-4.

69. Invernizzi G, Ruprecht A, De Marco C, Paredi P, Boffi R. Residual tobacco smoke: measurement of its washout time in the lung and of its contribution to environmental tobacco smoke. Tob Control 2007; 16:29-33 
70. Ueta I, Saito Y, Teraoka K, Miura T, Jinno K. Determination of volatile organic compounds for a systematic evaluation of third-hand smoking. Anal Sci 2010; 26:569-74.

71. Hammer TR, Fischer K, Mueller M, Hoefer D. Effects of cigarette smoke residues from textiles on fibroblasts, neurocytes and zebrafish embryos and nicotine permeation through human skin. Int J Hyg Environ Health 2011; 214:384-91.

72. Hang B, Sarker AH, Havel C, Saha S, Hazra TK, Schick S, et al. Thirdhand smoke causes DNA damage in human cells. Mutagenesis 2013; 28:381-91.

73. Karim ZA, Alshbool FZ, Vemana HP, Adhami N, Dhall S, Espinosa EV, et al. Third-hand smoke: impact on hemostasis and thrombogenesis. J Cardiovasc Pharmacol 2015; 66:177-82.

74. Jung JW, Ju YS, Kang HR. Association between parental smoking behavior and children's respiratory morbidity: 5-year study in an urban city of South Korea. Pediatr Pulmonol 2012; 47:338-45.

75. Bahl V, Weng NJ, Schick SF, Sleiman M, Whitehead J, Ibarra A, et al. Cytotoxicity of thirdhand smoke and identification of acrolein as a volatile thirdhand smoke chemical that inhibits cell proliferation. Toxicol Sci 2016; 150:234-46.

76. Xu B, Chen M, Yao M, Ji X, Mao Z, Tang W, et al. Metabolomics reveals metabolic changes in male reproductive cells exposed to thirdhand smoke. Sci Rep 2015; 5:15512.

77. Rehan VK, Sakurai R, Torday JS. Thirdhand smoke: a new dimension to the effects of cigarette smoke on the developing lung. Am J Physiol Lung Cell Mol Physiol 2011; 301:L1-8.

78. Kabir Z, Connolly GN, Alpert HR. Secondhand smoke exposure and neurobehavioral disorders among children in the United States. Pediatrics 2011; 128:263-70.

79. Chen JJ, Ho SY, Wang MP, Lam TH. Reactions to thirdhand smoke are associated with openness to smoking in young never smoking children. J Community Health 2016; 41:461-7.
80. Drehmer JE, Ossip DJ, Rigotti NA, Nabi-Burza E, Woo H, Wasserman RC, et al. Pediatrician interventions and thirdhand smoke beliefs of parents. Am J Prev Med 2012; 43:533-6.

81. Rendón AD, Unger JB, Cruz T, Soto DW, Baezconde-Garbanati L. Perceptions of secondhand and thirdhand smoke among Hispanic residents of multiunit housing. J Immigr Minor Health 2015; Epub ahead of print.

82. Pisinger C, Aadahl M, Toft U, Jørgensen T. Motives to quit smoking and reasons to relapse differ by socioeconomic status. Prev Med 2011; 52:48-52.

83. Williams RJ, Herzog TA, Simmons VN. Risk perception and motivation to quit smoking: a partial test of the Health Action Process Approach. Addict Behav 2011; 36:789-91.

84. McCaul KD, Hockemeyer JR, Johnson RJ, Zetocha K, Quinlan K, Glasgow RE. Motivation to quit using cigarettes: a review. Addict Behav 2006; 31:42-56.

85. Barnoya J, Navas-Acien A. Protecting the world from secondhand tobacco smoke exposure: where do we stand and where do we go from here? Nicotine Tob Res 2013; 15:789-804.

86. Programa das Nações Unidas para o Desenvolvimento. Acompanhando a agenda 2030 para o desenvolvimento sustentável: subsídios iniciais do sistema das Nações Unidas no Brasil sobre a identificação de indicadores nacionais referentes aos objetivos de desenvolvimento sustentável. Brasília: Programa das Nações Unidas para o Desenvolvimento; 2015.

87. Farber HJ, Groner J, Walley S, Nelson K; Section on Tobacco Control. Protecting children from tobacco, nicotine, and tobacco smoke. Pediatrics 2015; 136:e1439-67. 


\section{Resumo}

Recentemente, passou a ser discutida mais uma forma de exposição ao tabaco - thirdhand smoke (THS) - que consiste nos poluentes residuais da fumaça de cigarro que permanecem nos ambientes. A principal preocupação com o THS é embasada na presença e longa persistência de muitos compostos tóxicos, algumas nitrosaminas específicas do tabaco que têm atividade carcinogênica. Além de se saber pouco sobre o THS, poucos sabem de sua existência e preocupante repercussão na saúde. Coloca-se em destaque a necessidade de trazê-lo à luz e incluí-lo nas discussões, assim como foi feito com o tabagismo passivo alguns anos atrás, até mesmo porque o THS se caracteriza como uma forma de tabagismo passivo junto à exposição secundária ou involuntária da fumaça de cigarro.

Poluição por Fumaça de Tabaco; Tabaco; Fumaça

\section{Resumen}

Recientemente comenzó a ser discutida otra forma de exposición al tabaco -thirdhand smoke (THS)- que consta de contaminantes residuales de humo de cigarrillo que permanecen en el medio ambiente. La principal preocupación con la THS se basa en la presencia y larga persistencia de muchos compuestos tóxicos, como algunas nitrosaminas específicas que tienen actividad cancerígena. Pocos saben de la existencia de los THS y su impacto preocupante en la salud. Se plantea la necesidad de sacarlo a la luz e incluirlo en las discusiones, como se hizo con el tabaquismo pasivo hace unos años, incluso porque el THS se caracteriza como una forma de tabaquismo pasivo por la exposición secundaria o involuntaria de humo de cigarrillo.

Contaminación por Humo de Tabaco; Tabaco; Humo

Submitted on $26 / \mathrm{Feb} / 2016$

Final version resubmitted on 13/Jul/2016

Approved on 24/Aug/2016 